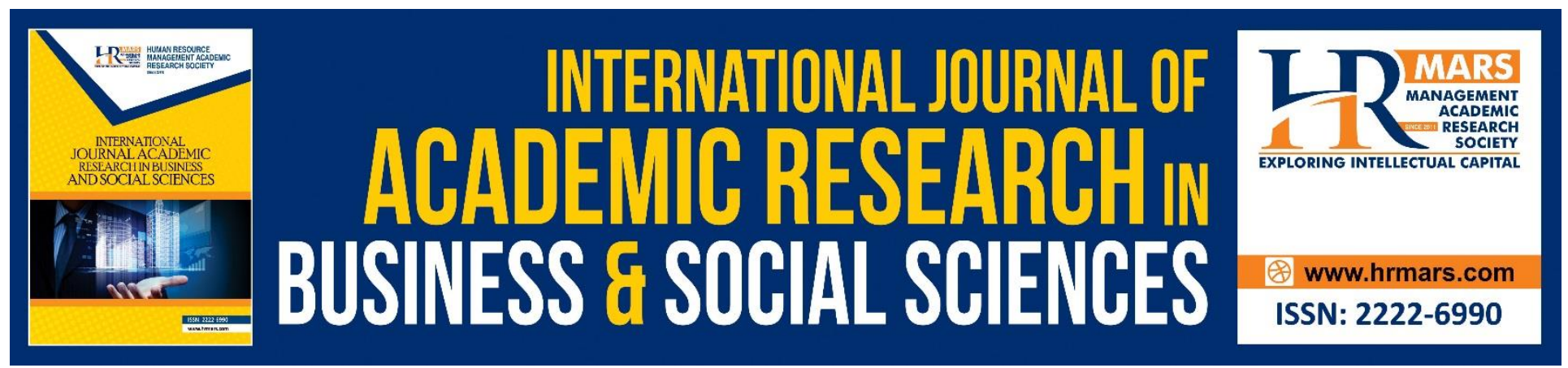

\title{
The Impact of Income Shock on Consumption Spending Among Young Malaysian Household with Credit Usage in Post Covid-19
}

Khairunnisa Abd Samad, Wan Musyirah Wan Ismail, Nordianah Jusoh @ Hussain, Nik Rozila Nik Mohd Masdek, Bushra Mohd Zaki, Nur Hayati Abd Rahman, Nur Hafidzah Idris

To Link this Article: http://dx.doi.org/10.6007/IJARBSS/v10-i8/7505 DOI:10.6007/IJARBSS/v10-i8/7505

Received: 11 May 2020, Revised: 14 June 2020, Accepted: 21 July 2020

Published Online: 19 August 2020

In-Text Citation: (Samad et al., 2020)

To Cite this Article: Samad, K. A., Ismail, W. M. W., Hussain, N. J. @, Masdek, N. R. N. M., Zaki, B. M., Rahman, N. H. A., \& Idris, N. H. (2020). The Impact of Income Shock on Consumption Spending Among Young Malaysian Household with Credit Usage in Post Covid-19. International Journal of Academic Research in Business and Social Sciences, 10(8), 110-120.

Copyright: @ 2020 The Author(s)

Published by Human Resource Management Academic Research Society (www.hrmars.com)

This article is published under the Creative Commons Attribution (CC BY 4.0) license. Anyone may reproduce, distribute, translate and create derivative works of this article (for both commercial and non-commercial purposes), subject to full attribution to the original publication and authors. The full terms of this license may be seen

at: http://creativecommons.org/licences/by/4.0/legalcode

Vol. 10, No. 8, 2020, Pg. 110 - 120

http://hrmars.com/index.php/pages/detail/IJARBSS

JOURNAL HOMEPAGE

Full Terms \& Conditions of access and use can be found at http://hrmars.com/index.php/pages/detail/publication-ethics 


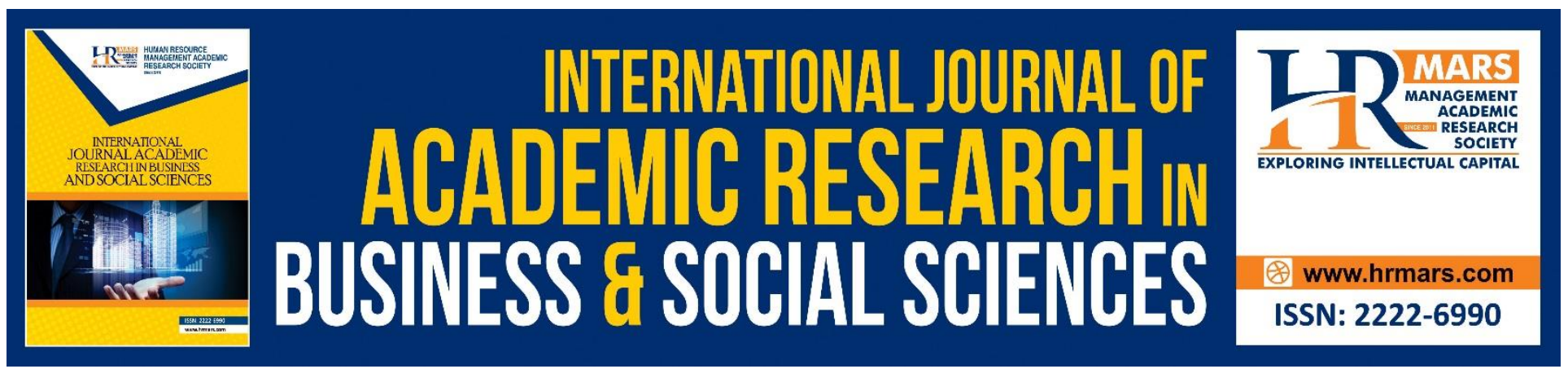

\title{
The Impact of Income Shock on Consumption Spending Among Young Malaysian Household with Credit Usage in Post Covid-19
}

\author{
Khairunnisa Abd Samad, Wan Musyirah Wan Ismail \\ Fakulti of Business Management, Universiti Teknologi MARA Cawangan Melaka
}

\author{
Nordianah Jusoh @ Hussain \\ Faculty of Computer \& Mathematical Sciences, Universiti Teknologi MARA Cawangan Melaka
Nik Rozila Nik Mohd Masdek, Bushra Mohd Zaki, Nur Hayati Abd Rahman, Nur Hafidzah Idris \\ Fakulti of Business Management, Universiti Teknologi MARA Cawangan Melaka
}

\begin{abstract}
For nearly 6 million young Malaysian in the labour force, Covid-19 will be especially damaging. They face the highest risk of unemployment. Their job opportunities will be severely curtailed by the contraction of the job market and with their comparatively lower incomes, many will struggle to feed their families. This study explores the conceptual framework on the impact of income shock on consumption spending among young household with debts. In this setting, the framework outlined the possible critical factors for suitable policy-formulation during Covid-19 for the government in sustaining the country's economic stability.
\end{abstract}

Keywords: Income Shock, Consumption Spending, Young Household, Credit Usage, Covid-19.

\section{Introduction}

During Covid-19, the Malaysian Institute of Economic Research, in a press statement on 24 March 2020, predicts that the real GDP growth of Malaysia in 2020 will drop from $4.0 \%$ to $-2.9 \%$, with up to 2.4 million job losses, of which $67 \%$ will be from the unskilled workers category. The Department of Statistic Malaysia (DOSM) survey conducted between March 23 to 31 March, during the second week of MCO phase one, from the 170,000 workers polled, showed half of those selfemployed reported to be out of work while up to a third said their income dropped by some 90 per cent. The statistics shows alarming concerns that the vulnerable household are exposed to income shocks. Moreover, the DOSM 2020 survey showed half of them have savings only enough to last them for two weeks, while only 28 per cent said they had enough to last them for two months. Hence, this situation raised the concerns among the policy makers. 
INTERNATIONAL JOURNAL OF ACADEMIC RESEARCH IN BUSINESS AND SOCIAL SCIENCES Vol. 10, No. 8, 2020, E-ISSN: 2222-6990 @ 2020 HRMARS

Following the concerns, Bank Negara Malaysia highlights that the sustainability of GDP growth in 2020 should be supported by stimulus measures, policy rate cuts, the continued progress of public projects and higher public sector expenditure. The Malaysian Government announced an Economic Stimulus Package totaling to RM250 billion to "cushion" the resulting impact from the COVID-19 pandemic outbreak, as well as "reinvigorate" the growth of the Malaysian economy through one of three different strategies: by boosting the household spending. Household would receive RM500 to RM1600 for two consecutive months, vary according to the groups: the bottom 40 (B40) and middle 40 (M40) groups. Nevertheless, the income received through this "pakej prihatin" seems insufficient for couple of months after Covid-19 crisis since the money is barely enough for the current state expenditure.

On the other hand, household with high level credit can be imprudent and vulnerable. As recorded in Cecchetti, Mohanty and Zampolli's work (2011), "Debt is a two-edged sword. Used wisely and in moderation, it clearly improves welfare. But, when it is used imprudently and in excess, the result can be disaster. For individual households and firms, over borrowing leads to bankruptcy and financial ruin."

The evolution of household indebtedness and its roots have been on the agenda of the economic discussion in the aftermath of the global financial crisis and now Covid-19 crisis. In some developing countries, households had increased their debt remarkably in the pre-crisis period which fueled the risk of over-indebtedness of households. Particularly, countries such as Thailand and Malaysia have recorded the highest household debt among the Asian countries. This raised the question as how the vulnerable household will react to income shocks such as job loss and the effect on consumption-related to high indebtedness level.

Motivated by the scenario discussed above, this paper explores the conceptual framework of income shocks on consumption related to young household indebtedness. The novelty of this study is to extend the household income-consumption nexus based on famous Ando and Modigliani's (1963) life cycle model and Friedman's (1957) permanent income hypothesis augmented with level of indebtedness in focusing on socio-demographic. According to life cycle model (LCM) and permanent income hypothesis (PIH), young people tend to have higher household debt due to higher desire for consumption. Nonetheless, mostly affected by the income shock are self-employed and young people who barely just getting their job before the pandemic. For Malaysia's nearly 6 million young people in the labour force, Covid-19 will be especially damaging (Welsh and Cheng, 2020). They face the highest risk of unemployment and their job opportunities will be severely curtailed by the contraction of the job market, and with their comparatively lower incomes, many will struggle to feed their families. Hence, the study intends to review the conceptual framework related to consumption spending among Malaysian household with high-level indebtedness particularly among the young household indebtedness.

The objective of this study is to explore the conceptual framework of income shocks on consumption related to young household indebtedness. The paper proceeds in the following ways: Section 2 briefly reviews previous studies on the related theories; Section 3 describes the conceptual framework and hypothesis; and Section 4 concludes the study. 
INTERNATIONAL JOURNAL OF ACADEMIC RESEARCH IN BUSINESS AND SOCIAL SCIENCES Vol. 10, No. 8, 2020, E-ISSN: 2222-6990 @ 2020 HRMARS

\section{Literature Review}

\section{Theoretical Framework}

The theoretical underlay which can explain the behavior of household consumption and related to debt reflected in the life cycle and permanent income hypotheses (Ando and Modigliani, 1963; Friedman, 1957; Modigliani and Brumberg, 1954). According to them, individuals save at an early age, accumulate wealth in the middle age, and dis-save at retirement days. They contended their belief which asserted that the levelling of household consumption maximized their function over time through the usage of both initial income and expected future income. As such, the household would borrow to smoothen their consumption over a lifetime. The hypothesis emphasized that lower than expected financial earnings motivated household borrowing. Nevertheless, in cases of an unexpected increase in income or during their most productive working days, the household would attempt to save. Furthermore, the household would use debt to finance present consumption and then repay the loans with the expected increase in future income. Hence, assuming that their income will increase during working years and decline at retirement, households tend to borrow when they are young, save during middle age, and spend down during retirement. So, the consumption will be a function of wealth, expected lifetime earnings and the number of years until retirement.

$$
C=(W+R Y) / T
$$

where $C=$ Consumption

$W=$ Wealth

$R=$ Years until retirement or years of work

$Y=$ Income

$T=$ Remaining years of life

\section{Income and Consumption Spending}

Income shock is an unpredictable or unexpected event that can affect the activities of consumer's spending and economy. They are affected mainly because of job loss, unemployment and salary cutting. According to Stevens (1997) and Been et al. (2020), an individual could face the effect of income shock because of job loss multiple times in their life cycle. They will suffer even more in the future because the liability of household debts increases especially if they fail to pay the debts according to the time frame. Especially during the Covid-19 pandemic, the probability for income shock to worsen is higher due to loss of jobs. This leads to the increment of the household debt and reducing the consumption sending. A research by Been et al. (2020) stated that $34 \%$ reduction on consumption spending due to job loss shock is equal to income shock. Moreover, three over five individuals under 40 years old in Malaysia lose their job because of the Covid-19 pandemic ("COVID19: 3 daripada 5 hilang pekerjaan berusia bawah 40," 2020). Based on MUTC (Kongres Kesatuan Sekerja Malaysia) statement, those who lose their job during this pandemic do not have enough saving even for a month. Therefore, their consumption sending worsens. Referring to Loke's (2016), more than 50\% Malaysian citizens do not properly plan their financial emergency and failed to meet the minimum guideline of having emergency funds equivalent to at least three months of living expenses if they lose their main source of income. These shocks have sizeable impacts of household income. In Malaysia, there are institutions such as PERKESO, which are actively monitoring the cases in job loss and layoffs all over the country during this pandemic ("Perkeso pantau kehilangan 
INTERNATIONAL JOURNAL OF ACADEMIC RESEARCH IN BUSINESS AND SOCIAL SCIENCES Vol. 10, No. 8, 2020, E-ISSN: 2222-6990 @ 2020 HRMARS

pekerjaan semasa krisis Covid-19," 2020). Therefore, income shock and consumer spending during this pandemic Covid-19 are widely affected.

Income shock also occur for unemployed individuals. During this Covid-19 pandemic, many of Malaysian citizen are left unemployed. According to DOSM 2020, Malaysian's unemployment rate increased from 3.3\% in February to $3.9 \%$ in the following month 2020 . The unemployment rate is increasing since Covid-19 pandemic began. Therefore, the household debt is also increasing. Besides that, there are research findings on unemployment and household debt which stated that both items are positively related (Meng et al., 2013; Jauch and Watzka, 2013; Hoang and Meng, 2015; Catherine et al., 2016; Ma'in et al., 2016). Based on Ganong and Noel (2017), there is a huge impact of decreasing in income when the individual is not being employed and this leads to decreasing of spending. However, during this Covid-19 pandemic, the consumer spending is increasing dramatically in an attempt to fulfil the needs of the households which consist of adult and children (Baker et al., 2020). Moreover, the need of income is important to maintain the needs to stockpile the goods at home since everyone need to stay home at all time during this pandemic. Individuals who are unemployed basically will have low liquidity. They basically have multiple strategies to smooth consumption including delays in recurring payments such as mortgages and credit card balances (Gelman et al., 2015). Therefore, unemployment will lead to income shock during this Covid-19 pandemic.

Another financial unpreparedness that leads to income shock is salary cutting. During the Covid-19 Movement Control Order (MCO) lockdown in Malaysia, a huge number of employees had their salary cut due to non-operating businesses and were struggling to pay rent and utility bills ("COVID-19: 3 daripada 5 hilang pekerjaan berusia bawah 40," 2020). Reported by the Straits Times on April 2020, one of the largest economy markets in the Malaysia, Genting Malaysia, had also proposed to cut their employees' salary up to $20 \%$ with very terms. They were also planning to reduce the workforce up to 15\% since the lockdown (Ngui and Chew, 2020). According to The Economic Times ("Malaysia's AirAsia founders not taking salary; staff accepts up to 75\% pay cut," 2020), the staff and management agreed that their salary will receive cuts between $15 \%$ to $75 \%$ based on level of seniority during this Covid-19 pandemic. This will give a big impact on the income, spending and household debt. They will struggle more because a lot of expenses, such as loans, need to be settled.

\section{Household Credit and Spending}

Studies on household debts in Malaysia emerge only recently when economists, academicians and policy makers begin to query and analyze their implications about the persistent increase in debts among Malaysian households (Rahman, Kosim and Yeok, 2016). In addition, it will have a negative impact and create financial instability when household debt levels are high (Azmin et al., 2019). Daljit (2019) from The Star newspaper reported that Malaysia's household debt exceeded 82.2 per cent of GDP as at the end of June 2019 compared to its peak of 86.9 per cent in 2015. This is one of Asia's largest and has surpassed that of other high-income nations like the United States (75.0\%) and Japan (58.2\%). A total of 300,908 Malaysians was declared bankrupt until August 2019, where 80,625 cases were included between 2015 and August 2019. Those aged 35 to 45 make up the majority of 28,296 cases or $35 \%$ during this period, followed by those aged 25 to 34 with 20,461 cases or $25.3 \%$. The young are affected by the latest patterns that see them spending more than they gain, said Minister in the Prime Minister's Department, Keong (“Over 300,000 Malaysians declared bankrupt," 2019). This statement backed by Baker et al. (2020) finding more spending in later periods by the young. 
INTERNATIONAL JOURNAL OF ACADEMIC RESEARCH IN BUSINESS AND SOCIAL SCIENCES Vol. 10, No. 8, 2020, E-ISSN: 2222-6990 @ 2020 HRMARS

Many of Malaysia's bankruptcy cases is largely due to the failure to manage debt as a result of hire purchase transaction, mortgage, personal loans, being a guarantor, and credit card debt trap (Adzis et al., 2017).

This study therefore seeks to examine the effects of Malaysia's household credit or debt and consumption spending during the COVID-19 pandemic in year 2020. Consumption should be predicted to have a positive and significant effect on household debt that has similar results with Beaton's (2009); Mutezo's (2014); Azmin et al.'s (2019). Beaton's study (2009) explores the relationship between aggregate consumer spending and credit availability in the U.S. The author noted that consumer spending is growing in response to an increase in the availability of credit. In addition, she provided a formal assessment of the possibility that when it undergoes major changes, credit availability will be particularly important for consumer spending. She estimated a consumption model in this regard, in which only large credit expansions and contractions influence spending. She concluded that significant adjustments in the availability of credit are especially important for the decisions on consumer spending. Such cycles appear to be correlated with times of high economic instability as can be predicted. These findings indicated that when modelling and predicting consumer spending, account should be taken of the availability of credit.

Consumption, on the other hand, may be a negative and significant relation to household debt. This was approved by Bunn (2014); Bunn and Rostom (2015); Ahmad Khan et al. (2016); Price et al., (2019). These researches show that indebted households during adverse macroeconomic shocks, such as the global financial crisis, reduce their spending by more than other households, but the negative impact of debt is also widespread during other periods.

Finally, it is also possible to connect insignificant relationships between consumption and household debt. Yet only two researches conducted by Andersen et al. (2016); Ganong and Noel (2017) agreed with the outcome of the prediction. From these findings, they have found that decreases in credit have no impact on borrowers' default or consumption.

\section{Young Malaysian Household and Spending}

Malaysian population comprises about 34\% of young adults, aged from 15 to 34 years old as revealed by Official Portal Economic Planning Unit (2010) and therefore, indicates the significant value of this cohort to businesses (Eze and Lee, 2012). Chan (2006) suggested that the business marketer should target the youth market as they possess huge purchasing power not only from themselves but those of their parents too. Grønhøj (2007) found that the purchasing decisions made by youngsters are often influenced by their social networks such as family members and friends. Social pressure is found to be the key determinant of consumption choices in this generation in which most of the decisions on spending were made impulsively (Penman and Mcneill, 2008). It normally developed by their needs to boost self-esteem, image consciousness and to be socially accepted by peers (Twenge and Campbell, 2008).

In consequence of social pressures and materialism, it is widely documented that compulsive spending and excessive debt is widespread among young generation nowadays (Penman and Mcneill, 2008; Pirog and Roberts, 2007; Yingjiao, 2008). Young people are easily tempted by the modern lifestyle, shopping and special packages given by credit card companies (Bianco and Bosco, 2002). Credit card firms often leverage on these lifestyle drivers to build long-term brand loyalty. Their need for temporary self-gratification without taking into account the impacts of over-indebtedness may cause the rise in interest charges, default and finally insolvency (Nga et al., 2011). 
INTERNATIONAL JOURNAL OF ACADEMIC RESEARCH IN BUSINESS AND SOCIAL SCIENCES Vol. 10, No. 8, 2020, E-ISSN: 2222-6990 @ 2020 HRMARS

The recent global crisis of Covid-19 has changed people's consumption spending pattern due to mobility restriction that has minimized the urge to spend as well as its hazard effects on income and economic. Coibion et al. (2020) remarked a tremendous drop in employment and consumer spending as well as a dreary outlook for the incoming few years. Chen et al. (2020) observed that the spending trend posits a strong negative sensitivity to the severity of the public health crisis as they claimed when the public health situation worsened, consumption plunged as well. The Covid-19 outbreak poses greater challenges to Malaysia's young household compared to overall population. They are at risk of being jobless and the declining job opportunities as most of the sectors have stopped their operation due to Movement Control Order imposed by the Malaysian Government.

Employment Insurance System (EIS) stated in a report titled "Employment Outlook, the 1st Quarter of 2020, Volume 4/2020, the Impact of Covid-19 on Loss of Employment (LOE)" that 61 per cent of job losses are among employees aged 40 and below, with 31 to 40 -year-olds accounting for 32 per cent and workers under 30 making up the remainder at 29 per cent ("Socso: Job losses in Malaysia increased by 42pc in Q1 due to Covid-19," 2020). Meanwhile, Welsh and Cheng (2020) revealed that apart from being susceptible to job losses and reduced opportunities, single young and households are also unlikely able to bear income drops due to their shortage of financial cushions and excessive level of debts. In addition, their report included that younger households have the lowest median incomes of any age group, excluding those who are retired. The situation is getting tense as these households normally have young families to be taken care of, which leads to additional monthly expenditures.

A 2018 Bank Negara Malaysia (BNM) paper reports that young people who make up a huge proportion of lower-income households are more likely have inadequate funds at hand to meet their debt obligations. In fact, the authors' calculations indicate that with a small reduction of $10 \%$ in household income would raise the insolvency risks among the households by more than $5 \%$. Hence, the situation for younger households tends to worsen than any previous assumptions, with the number of households reporting a total loss of income increasing during the Movement Control Order.

\section{Conceptual Framework}

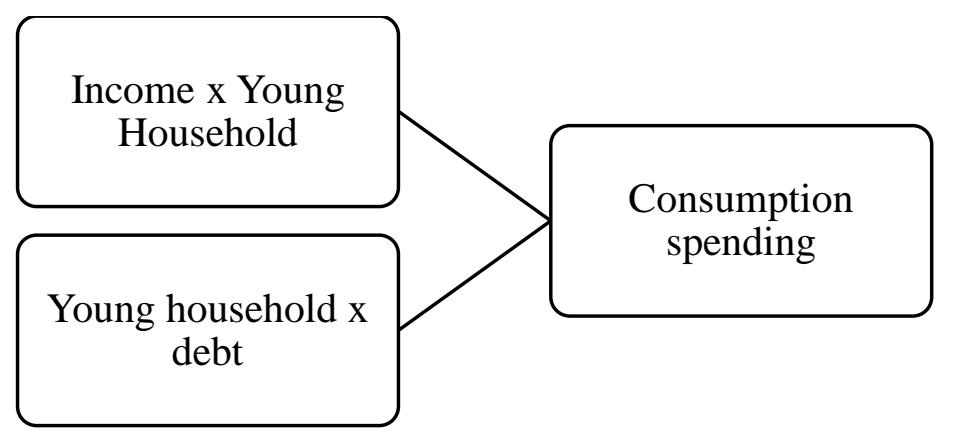

\section{Hypothesis}

On the other hand, the sudden shock of losing job may also influence households' decision on debt. Household debt is increased by low rate of unemployment signaled by the good labour market, subsequently indicating strong ability to pay off debt obligations as long as there is stability in household income generation. Hence, unemployment is one of the pivotal factors in determining the 
INTERNATIONAL JOURNAL OF ACADEMIC RESEARCH IN BUSINESS AND SOCIAL SCIENCES Vol. 10, No. 8, 2020, E-ISSN: 2222-6990 @ 2020 HRMARS

changes in household debt. Mian, Sufi and Verner (2017) found a high correlation between unemployment and household leverage in the US. Unemployment increases as households deleverage their debt. They further showed that non-tradable employment experienced a larger decline in counties with larger housing net worth declines using geographical variation across US counties. In addition, the young household is very much affected to the Covid-19 pandemic in the current situation. Therefore, the present model includes unemployment as an important variable. Here, unemployment and income are conditional term during pre- and post-Covid-19.

$$
C O N=f(I S Y)
$$

where, $C O N$ is household consumption is a function of ISD refer to the interaction term between income shock and young household.

Additionally, life cycle posits that the young households also play important roles in household borrowing, assuming that the income will be negative at the beginning of working life, so households tend to borrow when they are young, save during middle age, and spend down during retirement. The empirical evidence can be found in study Krishnan et al. (2015) shows that young individual or household is more exposed to financial accessibility particularly in borrowing and lending activities. Hence, it is argued that individual or household indebted during working age with expected future positive income, spends for wealth during middle age, and use up their savings during retirement days.

$$
C O N=f(I S Y, Y D)
$$

where, $C O N$ is household consumption is a function of ISD refer to the interaction term between income shock and young household and YD is referring to young household with indebtedness.

$\mathrm{H} 1=$ Income shock increases the influence of young household on consumption

$\mathrm{H} 2$ = Young people increases the influence of household indebtedness on consumption

\section{Conclusion}

As a conclusion, the Covid-19 crisis had its spill over impact in all over the world that may increase the downside risk of income shock on the consumption spending particularly among the young household indebtedness. In lieu of this, this study is motivated to explore the conceptual framework of income shocks on consumption related to young household indebtedness. The novelty of this study is to extend the household income-consumption nexus based on famous Ando and Modigliani's (1963) life cycle model and Friedman's (1957) permanent income hypothesis augmented with level of indebtedness in focusing on socio-demographic. The selected variables are discussed, and it is expected that income shock in Malaysia such as job loss and unemployment is high and can be factors to change the household spending in Malaysia. In addition, the level of credit can play an important role, given the household is affected with the income shock. However, the Bank Negara Malaysia Moratorium is expected to reduce the burden and stabilize the household spending.

\section{Corresponding Author}

Khairunnisa Abd Samad,

Affliation: Universiti Teknologi MARA Kampus Alor Gajah, Km 26 Jalan Lendu, 78000, Alor Gajah, Melaka, Malaysia.

Email: khairunsamad84@gmail.com 
INTERNATIONAL JOURNAL OF ACADEMIC RESEARCH IN BUSINESS AND SOCIAL SCIENCES Vol. 10, No. 8, 2020, E-ISSN: 2222-6990 @ 2020 HRMARS

\section{References}

Adzis, A. A., Bakar, J. A., \& Shahar, H. K. (2017). Factors influencing young adults' debt in Malaysia. Journal of Business and Retail Management Research, 12(1).

Khan, A. H. H., Abdullah, H., \& Samsudin, S. (2016). The linkages between household consumption and household debt composition in Malaysia. International Journal of Economics and Financial Issues, 6(4), 1354-1359.

Andersen, A. L., Duus, C., \& Jensen, T. L. (2016). Household debt and spending during the financial crisis: Evidence from Danish micro data. European Economic Review, 89, 96-115.

Ando, A., \& Modigliani, F. (1963). The" life cycle" hypothesis of saving: Aggregate implications and tests. The American Economic Review, 53(1), 55-84.

Azmin, N. A. M., Zaidi, W. N. W., \& Mohamad, Z. (2019). The Determinants that Influence Household Debt Case in Malaysia. KnE Social Sciences, 1215-1226.

Baker, S. R., Farrokhnia, R. A., Meyer, S., Pagel, M., \& Yannelis, C. (2020). How does household spending respond to an epidemic? consumption during the 2020 covid-19 pandemic (No. w26949). National Bureau of Economic Research.

Beaton, K. (2009). Credit constraints and consumer spending (No. 2009-25). Bank of Canada.

Been, J., Suari-Andreu, E., Knoef, M., \& Alessie, R. (2020). Consumption responses to unemployment shocks. Netspar Academic Series. DP01/2020-005

Bianco, C. A., \& Bosco, S. M. (2002). Ethical issues in credit card solicitation of college students-The responsibilities of credit card issuers, higher education, and students. Teaching Business Ethics, 6(1), 45-62.

Bunn, P. (2014). Household debt and spending. The Bank's Structural Economic Analysis Division and May Rostom of the Bank's Banking System Division, United Kingdom.

Bunn, P., \& Rostom, M. (2015). Staff Working Paper No. 554 Household debt and spending in the United Kingdom.

Catherine, S. F. H., Jamaliah, M. Y., Aminah, M., \& Arshad, A. (2016). Household debt, macroeconomic fundamentals and household characteristics in Asian developed and developing countries. The Social Sciences, 11, p4358-4362.

Cecchetti, S. G., Mohanty, M., \& Zampolli, F. (2011). Achieving growth amid fiscal imbalances: the real effects of debt. In Economic Symposium Conference Proceedings (Vol. 352, No. August, pp. 145-96). Federal Reserve Bank of Kansas City.

Chan, K. (2006). Young consumers and perception of brands in Hong Kong: A qualitative study. Journal of Product and Brand Management. 15(7), 416-426.

Chen, H., Qian, W., \& Wen, Q. (2020). The Impact of the COVID-19 Pandemic on Consumption: Learning from High Frequency Transaction Data. Available at SSRN 3568574.

Coibion, O., Gorodnichenko, Y., \& Weber, M. (2020). The cost of the covid-19 crisis: Lockdowns, macroeconomic expectations, and consumer spending (No. w27141). National Bureau of Economic Research.

COVID-19: 3 daripada 5 hilang pekerjaan berusia bawah 40. (2020), Berita Harian. Retrieved from https://www.bharian.com.my/berita/nasional/2020/06/700243/covid-19-3-daripada-5-

hilang-pekerjaan-berusia-bawah-40

Daljit, D. (2019). Household debt to GDP may inch up. The Star. Retrieved from https://www.thestar.com.my/business/business-news/2019/12/16/household-debt-to-gdpmay-inch-up 
INTERNATIONAL JOURNAL OF ACADEMIC RESEARCH IN BUSINESS AND SOCIAL SCIENCES

Vol. 10, No. 8, 2020, E-ISSN: 2222-6990 @ 2020 HRMARS

Department of Statistic Malaysia (2020). Laporan Analisis Survei Khas Kesan COVID-19 Kepada Ekonomi dan Individu. https://www.dosm.gov.my/v1/uploads/files/covid19/Analisis_Survei_Khas_Kesan_COVID-19_Kepada_Ekonomi_dan_IndividuLaporan_Penuh.pdf

Eze, U., \& Lee, C. (2012). Consumers' Attitude towards Advertising. International Journal of Business and Management, 7(13).

Friedman, M. (1957). A Theory of the Consumption Function. Princeton: Princeton University Press.

Ganong, P., \& Noel, P. (2017). The Effect of Debt on Default and Consumption: Evidence from Housing Policy in the Great Recession. Harvard University, United States.

Gelman, M., Kariv, S., Shapiro, M. D., Silverman, D., \& Tadelis, S. (2015). How individuals smooth spending: Evidence from the 2013 government shutdown using account data. Cambridge, MA: National Bureau of Economic Research.

Gronhoj, A. (2007). The consumer competence of young adults: A study of newly formed households. Qualitative Market Research, 10(3), 243-264.

Hoang, N., \& Meng, S. (2015). The Rising Australian Household Debt: Results from A Bayesian VAR Analysis. Unpublished paper. Retrieved from https://www.uml.edu/docs/Housing_Paper_tcm18-154277.pdf

Jauch, S., \& Watzka, S. (2013). The Effect of Household Debt Deleveraging on UnemploymentEvidence from Spanish Provinces. In conference paper, Beiträge zur Jahrestagung des Vereins für Socialpolitik.

Krishnan, K., Nandy, D., \& Puri, M. (2015). Does financing spur small business productivity? Evidence from a natural experiment. The Review of Financial Studies, 28(6), 1768-1809.

Loke, Y. J. (2016). Financial preparedness for income shock among Malaysians. Malaysian Journal of Economic Studies, 53(2), 279-295.

Ma'in, M., Tajuddin, N. I., \& Nathan, S. S. (2016). Household Debt and Macroeconomic Variables in Malaysia. In 3rd International Conference on Business and Economics (Vol. 3, pp. 21-3).

Malaysia's AirAsia founders not taking salary; staff accepts up to $75 \%$ pay cut (2020). The Economic Times. Retrieved from https://economictimes.indiatimes.com/news/international/business/malaysias-airasiafounders-not-taking-salary-staff-accepts-up-to-75-pay-cut/articleshow/75104956.cms

Meng, X., Hoang, N. T., \& Siriwardana, M. (2013). The determinants of Australian household debt: A macro level study. Journal of Asian Economics, 29, 80-90.

Mian, A., Sufi, A., \& Verner, E. (2017). Household debt and business cycles worldwide. The Quarterly Journal of Economics, 132(4), 1755-1817.

Modigliani, F., \& Brumberg, R. (1954). Utility analysis and the consumption function: An interpretation of cross-section data. Franco Modigliani, 1(1), 388-436.

Mutezo, A. (2014). Household debt and consumption spending in South Africa: an ARDL-bounds testing approach. Banks and bank systems, (9, Iss. 4), 73-81.

Nga, J., Yong, L., \& Sellappan, R. (2011). The influence of image consciousness, materialism and compulsive spending on credit card usage intentions among youth. Young Consumers, 12(3), 243-253.

Ngui, Y., Chew, E. (2020). Genting Malaysia is said to cut $15 \%$ of its workforce. The Edge Market. Retrieved from https://www.theedgemarkets.com/article/genting-malaysia-mulling-3000-jobcuts-\%E2\%80\%94-report 
INTERNATIONAL JOURNAL OF ACADEMIC RESEARCH IN BUSINESS AND SOCIAL SCIENCES

Vol. 10, No. 8, 2020, E-ISSN: 2222-6990 @ 2020 HRMARS

Over 300,000 Malaysians declared bankrupt. (2019). Free Malaysia Today. Retrieved from https://www.freemalaysiatoday.com/category/nation/2019/10/17/over-300000-malaysiansdeclared-bankrupt/

Penman, S., \& Mcneill, L. (2008). Spending their way to adulthood: Consumption outside the nest. Young Consumers, 9(3), 155-169.

Perkeso pantau kehilangan pekerjaan semasa krisis Covid-19. (2020), Sinar Harian. Retrieved from https://www.sinarharian.com.my/article/80591/BERITA/Nasional/Perkeso-pantaukehilangan-pekerjaan-semasa-krisis-Covid-19

Pirog, S., \& Roberts, J. (2007). Personality and credit card misuse among college students: The mediating role of impulsiveness. Journal of Marketing Theory and Practice, 15(1), 65-77.

Price, F., Beckers, B., \& La Cava, G. (2019). The effect of mortgage debt on consumer spending: evidence from household-level data (No. rdp2019-06). Reserve Bank of Australia.

Rahman, N. A. A., Kosim, Z., \& Yeok, S. G. (2016). Household Indebtedness in Malaysia: A Survey Evidence. International Journal of Trade, Economics and Finance, 7(4), 102-104.

Socso: Job losses in Malaysia increased by 42pc in Q1 due to Covid-19 (2020), Malay Mail. Retrieved from https://www.malaymail.com/news/malaysia/2020/06/03/socso-job-losses-in-malaysiaincrease-by-42pc-in-q1-due-to-covid-19/1872211

Stevens, A. H. (1997). Persistent effects of job displacement: The importance of multiple job losses. Journal of Labour Economics, 15(1, Part 1), 165-188.

Twenge, J., \& Campbell, S. (2008). Generational differences in psychological traits and their impact on the workplace. Journal of Managerial Psychology, 23(8), 862-877.

Yingjiao, Y. (2008). The influence of public self-consciousness and materialism on young consumers' compulsive buying. Young Consumers, 9(1), 37-48.

Welsh, B., \& Cheng, C. (2020). Malaysia's youth on the frontlines of the COVID crisis. Institute of Strategic and International Studies (ISIS) Malaysia. Retrieved from https://www.isis.org.my/wp-content/uploads/2020/04/Youth-unemployment-frontline.pdf 